\title{
'Children must be seen and heard' - Doing postcolonial theology with children in a (southern) African Reformed church
}

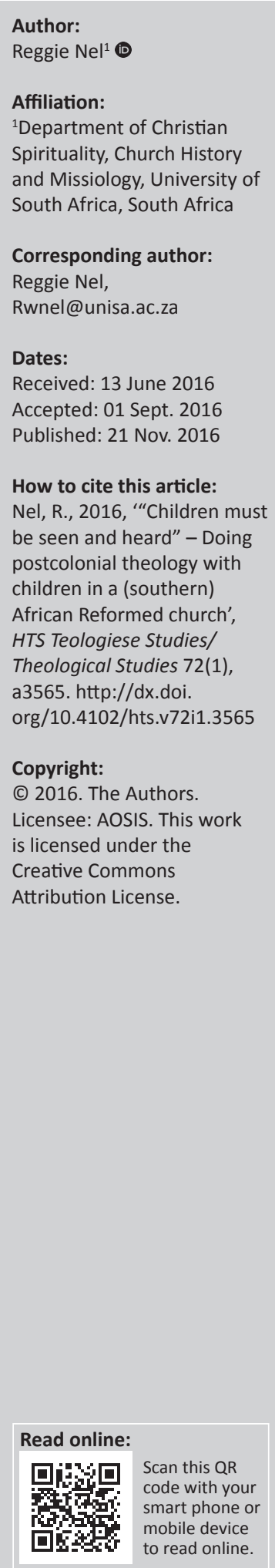

Taking theology to the African children needs to start with a serious engagement of the colonial experience that African Christianity, communities and families were subjected to mostly in subdued silence. The often heard platitude of the stereotypical 'friendly' African children, who is so 'open to the gospel', needs to be deconstructed in terms of the real challenges, which leads to migration, abuse, xenophobic violence and a serious reduction in their capacity for growth and development. While one cannot reduce the notion of 'African children' to one experience, there remain common structural realities, which call for a serious dialogue with themselves on their own forms of theology. Children are not anymore merely seen and not heard; they speak - they disrupt hegemonic colonialist theologies. This contribution is based on a postcolonial dialogue with children's ministries in a particular (southern) African mission church, as they transform themselves towards being an African Reformed community.

\section{Introduction}

We grew up with the adage, 'Children must be seen and not heard'. When these words were said, it usually served as a stern warning. This was also our experience as children growing up in what was known as the Nederduitse Gereformeerde Sendingkerk in Suidelike Africa ['Dutch Reformed Mission Church'] (DRMC), a black mission church established in South Africa, Namibia and some small parts of southern Botswana. For us, it would seem that silence or voicelessness and a rigid adherence to a strict liturgical order, inherited from the white 'mother church', which usually included solemn hymns accompanied by an organ, were the signs of true Dutch Reformed worship. Before entering this (Dutch Reformed) worship service, whether coming from Sunday school, or after marching through the streets in the youth brigade (organisations which I will explain later in the article), we would again hear the stern warning from our Sunday school teachers and at other times, the elders - children must be seen and not heard.

This silencing is largely still the reality for children and young people in churches - not only the worship services in the various Dutch Reformed churches in (southern) Africa, but also in how theology is practised in this region. These younger believers, irrespective of their own agency, may be seen, or better, gazed upon, targeted theologically and eventually ministered to by evernew children's evangelism campaigns, yet they are not to speak up for themselves. Unlike what is often projected as the 'angry' black theologian, or the resilient African theologian, 'obsessed with their traditional rituals', the African children are often constructed as so 'friendly' and 'open to the gospel' - ready for the taking. They have been (and remain still), largely, the soft targets of mission campaigns and strategies to ultimately conquer and dominate the 'Dark Continent'.

Therefore, this contribution, from a particular (southern) African Reformed experience, argues that unless this imperial, colonial experience of African Christians and churches, including their youngest worshippers and witnesses, are taken serious in ministries with children, and unless they are allowed to disrupt domineering practices, these imperial mission campaigns and strategies, and its concomitant theologies, will not be able to seriously address the heart of the plight of African children. In building this argument, I gained from the insights of educationalists, Gaile S. Canella and Radhika Viruru (2004), who propose a postcolonial engagement which takes the important issues of power and the colonial history seriously. Through this postcolonial lens and drawing substantially on my doctoral research ( $\mathrm{Nel} 2013)$, I then present a narrative from one mission church, as already mentioned the DRMC, and the challenge, or better the disruption by children and young people themselves to a particular colonial missionary ecclesiology. Lastly, 
I present an alternative postcolonial missional ecclesiology, as the basis for taking seriously the agency of African children as witnesses in their own right. As indicated, I do this narratively, by reflecting on where we come from as children of a particular (southern) African Reformed church, breaking away from the missionary paradigm where initially the daughter mirrors the mother, towards where then the daughter starts to speak, and lastly, allowing the imposed Eurocentric colonial theologies to be interrupted and transformed by new voices, where the daughter becomes an African mother. As indicated, I however start by arguing for a particular theoretical framework.

\section{Childhood and postcolonisation}

In their work, early childhood educators, Cannella and Viruru (2004) draw insights from the postcolonial theorists in a critique of what they call, 'developmentally appropriate practice' (p. 2) for those who are younger. They want to step out of existing dominant childhood theories, which for them, remain Western. They explain:

We believe that we must stop looking at childhood as an isolated phenomenon, intelligible only through the lenses of 'experts' who have studied the child through the dominant telescope of Western discourses like psychology. We believe that we must start thinking about those who are younger as people who are part of a much larger and complex whole, as linked to and influencing the larger and more complex world. (p. 3)

In addressing this sensitive theme, they argue that the knowledge base from which childhood education worked, namely developmental theory, educational learning theories, psychology, etc. generally, was 'incomplete and partial' (p. 4). Therefore, the notion of 'childhood' itself can also be seen as a colonising construct, and these labels, forms of representation and positions imposed on those who are younger can be 'oppressive, controlling, and even colonizing' (p. 83). In this, they find value in the theoretical work of Hohmi Bhabha for example in the discussion of the production of the 'other' through surveillance and the creation of what Bhabha calls, a 'subject people' - 'lacking and in need of control by those who have generated the knowledge' (p. 84). They also refer to the work of Edward Said in the construction of the 'orient', as European inventions, 'visions that imposed constructions of the "other" as exotic and romantic' (p. 84). They describe how Western ideas of Enlightenment and contemporary modernism played a role in the social construction of the child (p. 86) in relation to the physical colonisation and imperialism by the same developers of enlightened and modern systems of thought. In this regard they argue that the:

populations of mostly indigenous populations of colour became part of the discourse of progress that privileged White European male adults and placed those who were younger (labelled 'children') and colonised peoples in much the same positions called savaged, incompetent, out of control, and incomplete. (p. 87)

This is based on the distinction by Cannella and Viruru between imperial projects, which means the physical occupation to civilise and exploit with the purpose to establish imperialist structures on the one hand, and then, on the other hand, colonial projects which were undertaken lacking any kind of 'ideological mission that would bring civilisation to the natives or channel new financial resources to the centre of the Empire' (p. 14). They show that these actions caused mass unsettlement for the original inhabitants, or even extermination, and that it correlates with how children were constructed also in the colonies. While I will not (again) explain the reception of the postcolonial critique for theology (see De Jong-Kumru 2014; Segovia 1999, Sugirtharajah 1999, 2001, 2003), it is important here to simply refer to their appropriation of it for a critique of existing theories on childhood, but also doing theology.

In the next section, I draw on my doctoral research to turn now to the experience of the former DRMC, and the postcolonial challenge, or better the disruption by children as younger people and younger believers themselves.

\section{The daughter, the mirror and the moeder}

The popular view in the black communities was that the DRMC was a mirror image of the white Nederduitse Gereformeerde Kerk ['Dutch Reformed Church'] (NGK), also called the moederkerk ['mother church'] (Kinghorn 1997:151-154). For us, as children of this tradition, being a Reformed Christian engendered participation in the children and youth associations of our denomination, namely at the time, the Christelike Kinderbond ['Children's Christian League'] (CKB), the Kerkjeugbrigade ['Church Youth Brigade'], Christelike Jongdogtersbond ['Christian Young Daughter's League'] and the Christelike Jeugvereniging ['Christian Youth Association'] (CJV). As membership-based organisations within the church and alongside Sunday school and catechism, these organisations represented the children's and youth ministry of the DRMC.

These structures were largely the fruit of the missionary activities of the white mother church, the NGK, in following its strict forms. Crafford (1982:543), in his study of the DRC mission work in southern Africa, explains how, amongst others, the Transvaalse Vroue-Sendingvereniging ['Transvaal Women's Missionary Association'] (TVSV) viewed specifically the black children and youth as a special field of mission for them. This missionary interest included the raising of funds and the appointment of a white youth minister, Rev. Jan Hofmeyer in the NGK, who coordinated crèches, childcare facilities, youth camps, religious education at schools, youth clubs, choirs and youth hostels. Crafford recalls:

Vir al hierdie projekte het die TVSV ruim bygedra. So het Blanke moeders meegewerk aan en gebid vir die heil van Swartkinders. ${ }^{1}$ (p. 543)

The NGK also started what was called a Kindersendingkrans ['Children's missions league'](KSK), within their own white structures, which aimed at supporting its missionary

1.'For all these projects the TVSV contributed generously. In this way have White mothers co-operated to and prayed for the salvation of Black children'. 
endeavours (Crafford 1982:548f.). This ministry was duplicated in the DRMC as the CKB. The black children and young people, the objects of these mission campaigns on the other side, would in line with these structures and endeavours, gather in racially constructed mission churches at regular times during the week, mostly inside church buildings. Here for us, as children of this tradition, these meetings would start with some singing of choruses and opening prayer and then older youth leaders or adult volunteers would present the prescribed programmes to us, varying from cultural activities, recreation and fun activities to a Bible lesson. Most of these programmes and activities were prescribed from a central office, initially organised and written by the wives of the missionaries (Crafford 1982:206-207), while the CJV and Brigade were structured strictly according to a formal set of regulations (Skema van Werksaamhede van die NGSK 1982a:265-271, 279, 282, 1986a:506-509, 513-518, 520-521). This model and particular self-understanding of children's and youth ministry framed as strictly gereformeerd were controlled by the white missionaries and their wives leading our church and as indicated were followed in strict accordance with the practices and ecclesiology of various white-led missionary societies and the NG Moederkerk (Bosch 1991:490, Crafford 1982:206-207; Kriel 1963:169-175, 235-247; Nel 1983:93-97; Terblanche 1966:40-51). While this children-must-be-seen-andnot-heard pattern and the ecclesiology behind it were silently accepted in the separate institutions as 'our church'; however, this daughter grew up and started to raise her voice.

\section{The daughter raises her voice - Disruption}

Ongoing contestation and consequently transformation gradually became the reality of these ministries as the children became students (Boesak 1984:27; Durand 1984:123-126; Robinson 1984:50-51). Small, but significant, elements of the faith experience from the DRMC started to include (informally) a mixture of popular spirituality and freedom songs from North American black churches (Boesak 1977:41). This expression of spirituality resonated culturally with the younger members and therefore also started to challenge the dominant official Dutch Reformed gereformeerde missionary religious self-understanding, as well as the forms of faith and engagement. These were more and more expressed informally, for example at children's gatherings, youth camps, in vigorous singing and dancing on the rhythm of what was called koortjies ['choruses'] 2, 'spirituals's and freedom songs, parallel to a pietist spirituality of 'giving your heart to Jesus' ${ }^{\prime 4}$ that required personal getuienis [testimony] and a strong emphasis on a puritanical personal life. These

2.These songs were usually highly rhythmic and two- or three-line choruses sung repeatedly accompanied by the clapping of hands and sometimes rhythmic processions around the hall, in circles or different formations, depending on the leader. This style of singing was influenced by Pentecostal spirituality, although it was expressed in a less ecstatic tone and style.

3.Biko (1978:47) is correct, in my view, when he said that 'the so called Negro spirituals sung by the Black slaves ... under oppression' indicated their African origin. For us, apart from singing of these 'spirituals' in harmonising male choirs and church choirs, they were also sung at youth events and choir competitions, with the appropriate they were also sung at youth events and choir compe
rhythmic processions, body movements and gestures.

4.This meant that when you were converted which implied that you observed total abstinence from alcoholic beverages, smoking, the use of vulgar language, dancing to popular music, etc. forms of popular Christianity were steeped in a deeply evangelical ethos. Ironically Allan Boesak (1966:77-79), as a theological student at the time, and later, with his older brother fondly referred to as 'Uncle' Reggie Boesak, one of the most well-known children and youth dominees, at the time, lamented at some point the fact that the DRMC was so slow in developing a youth association, but also, that this church often only organised only social events for children and young people. He argued for a stronger 'spiritual' component that would give direction in the development of the movement:

Wat help al die konferensies, die kongresse, jeugleiers-kursusse, goedbeplande jeugweke, as ons nie die dinge wat ons daar leer in die werklike lewe gaan konkretiseer nie [...] Dit bring ons tegelykertyd by die grootste gebrek in ons Christelike verenigingslewe: geestelike werk. Daarom is die Christen jongmens daar: om sy mede-jongoriend na Jesus te lei. ${ }^{5}$ (p. 79)

Indeed, while the focus of the ministries with the younger members, at the time, was at its heart on this important spiritual and evangelistic thrust, on the other hand, as indicated, since the early 1970s, the child became a teenager and student. Under the leadership of these same ministers and youth leaders, particularly from the University of the Western Cape (UWC) and various Teacher Training colleges, emerged strong opposition to the silencing as a form of colonial subjugation.

This raising of her voice not only consciously found expression in the popular forms of spirituality, but also theologically in what became known as South African Black Theology. It was framed at the time, not only as 'relevant' Bible studies, but also political debates, stances and protests by our children and youth volunteers in congregations who were involved in the youth congress movement and other student movements. These student movements fundamentally shaped the social and political consciousness of our church's younger members (Boesak 2009:157-158). This shift took place gradually as these Christian youth and student associations remained in dialogue with this wide array of politically conscious and activist student movements. It was friends, schoolmates and leaders in our congregations, still in various primary and high schools, who were shot in the back in 1976, and even as primary school learners, they would be arrested for their activism in the struggle against apartheid. As a result, youth camps, conferences, and to a very small degree, our worship services, now termed, 'youth services', increasingly became the space for not only raising the voices (and fists!) in the singing of the spirituals, koortjies and freedom songs, but also 'relevant' and 'contextual' Bible studies, for learners from primary schools to tertiary institutions to tell their stories. The structures and forms of gereformeerde, as well as the narrow popular pietist spirituality - inherited from the missionaries - were openly challenged. More importantly, however, they were re-invented into democratic spaces for younger Christians

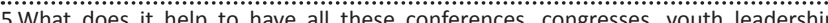
courses, well-planned youth weeks if we don't concretise the things we learn in real life.... It brings us to the biggest lack in our Christian associations: spiritual work. That is why the Christian young person exists: to leads a fellow young person to That is why the Christian
Jesus. [My translation] 
imbued with the ethos of the congresses of the various liberation movements. As now a leading voice within (what later became known as) the first phase of South African Black Theology, Boesak was also the student chaplain for the DRMC in Bellville - playing the role of forming the next generation of leaders in the DRMC. He forcefully articulated this theological challenge within that context, in a speech at the Annual General Meeting of the SACC in 19796, which he also quotes at length in a recent publication (Boesak 2009). This speech followed on the turbulent period after the watershed 1976 uprisings of learners and tertiary students, as well as the death of student leader and Black Theologian Steve Biko in police custody in 1977. Boesak recognised that Biko's struggle itself was not simplistically 'political', but against a colonial conception of church and mission, in which generational elitism and the silencing of the younger voices shaped the reading of the gospel. This in turn, led to a particular structuring of church and society. Biko spoke as a younger person and student leader. He envisioned the formation of church as a faith movement that transcends the boundaries of language, ethnicity, racial but also generational identities which foregrounds the agency of a younger, black humanity to induce social and personal healing as well as transformation. This understanding suggests an ecclesiology that aims consciously to transcend and subvert colonial and elitist missionary ecclesiologies forged in a particular context. The question is whether this agency from younger generations was taken up into the established institutions and formal theological trajectories.

With the exception of perhaps Allan Boesak, Takatso Mofokeng (1983:6-9) and Tinyiko Maluleke (2008:116-119), it seems however that this challenge of children and younger people was not always reflected on consciously as a critical contribution to the development of South African Black Theology. Boesak delivered, as referred to earlier, his classic speech (1984:22-35) where the challenges from Biko for the church clearly surface. Boesak (2009[1979]) said:

We had all heard Biko, and we all knew we had to respond. We were facing a new generation of young black Christians: politically astute, sensitive to what they were being told, knowing the dilemmas of the black church, and articulate in their anger, critique and aspirations. (p. 44)

This affirmation of and dialogue with the daughter raising her voice, i.e., young people, learners and students, as alluded to earlier, were certainly influenced by Boesak's experience as a student chaplain at the UWC in the middle of the 1970s. In this speech initially to the leadership of the South African Council of Churches in 1979 he made it clear that it was out of the legacy of the struggle of the young people that the reconceptualisation of new church now called the black church had to emerge, albeit a preliminary and an incomplete challenge. He conceded at the time, 'It is my contention that the Black church does not yet know how to deal with this new generation' (2009[1979]:54).

6.This speech was also published in Black and Reformed: Apartheid, Liberation and the Calvinist Tradition (Boesak 1984), but the reason why I work with the text in Running Calvinist Tradition (Boesak 1984), but the reason why I work with the text in Running
with Horses (Boesak 2009) is because in it Boesak himself gives some insightful and with Horses (Boesak 2009) is because in it Boesak himself gives some insight
reflexive comments which are crucial for the interpretation of this speech.
The role of these disruptions and challenges did indeed impact on the mission churches, as well as the broader transformations of at least this particular (southern) African society. This is however an ongoing challenge towards transformation.

\section{From disruption to transformation}

From a dialogue with youth and student movements, it seems as if these disruptions continued to challenge a transformation that is to take place on the level of inherited colonial theologies and therefore the conscious and unconscious images and models of church - the missionary ecclesiology. In this pilgrimage with the younger members of churches, I argue that being on a pilgrimage of transformation, being 'at the cross-roads', becomes the church's ongoing challenge and reality. It not only challenges children and youth ministries towards better communication of the gospel or towards a more effective education system, but this dialogue also challenges the colonial ecclesiologies itself. How does this relate to doing a postcolonial theology with children and young people?

Within youth ministry scholarship, related to ecclesiology, Pete Ward (2002), in particular, refers to this ongoing reality as 'liquid culture' (p. 2), in line with sociologists Zygmund Bauman's notion of 'liquid modernity' and Manuel Castells' reference to the 'flows' in the Network Society. They point to a flexible and constantly changing environment, which impacts on technological developments, organisational change, economics and social structures. This forms the basis then for Ward's proposal for a 'liquid church'. This metaphor, for Ward, does not speak of a church that 'floats upon' a constantly changing environment, but it starts from the positive elements in the new, fluid environment and tries to work with these and make them part of the way forward for the church. Change is the reality of church. To be liquid church means for Ward that the church is able to combine with water to become fluid, changeable, flexible and so on. The church need to embrace and internalise the liquid nature of culture rather than learn to sail through it (p. 3). South African Dutch Reformed practical theologian Malan $\mathrm{Nel}$ (2001) in trying to also come to terms with the challenge from children and young people, however, speaks of the challenge of radikale verandering ['radical change'] and even 'revolution'. He states:

The revolution that youth ministry [and children's ministry] puts on the table, is not of an incidental nature, which draws the attention of individuals and eventually also the churches on youth, inside, but specifically outside homes. This revolution continues daily. Some societies, for example the South African society, experience only now something of the industrial and youth revolution which hit other countries, in the middle of the 19th and 20th centuries, respectively. (pp. 9-10)

While these reflections resonate with the disruption and challenge from younger members I found in my dialogue with youth and student movements (Nel 2013:200-313), I would argue, however, in line also with the narrative of the 
DRMC as presented earlier, that one also needs to bear in mind the continued salience of power structures, as is still manifested in political, economic interests and contestations as raised by Castells $(2010,2012)$. Hence, we need to also consider the challenge by David White (2005) as he proposes, what he consciously calls, 'a transformative youth ministry approach'. White states:

Popular youth ministry in its worst forms leaves young disciples ill equipped to engage the powers and principalities that encompass adolescent life, fostering instead an abstract Christian identity that knows little of the wounds or blessings of their particular world. There is no such thing as Christian discipleship in general, but Christian faith and practice require incarnation in particular times and places. For too many Christians, their faith is held as a romantic abstraction focused on deep personal beliefs or a world beyond, but ignores how the Spirit is working within history, and how all of creation (including their neighbourhood) is groaning for transformation. (p. 5)

There is indeed a stronger resonance with a transforming reality and therefore the notions of a 'transforming mission' (Bosch 1991). I would therefore not use notions like 'radical' or 'revolution' in a metaphorical sense. These notions remain important, in terms of the theological heritage and disruption as referred to earlier in the DRMC narrative, and therefore, 'radical change' and 'revolution' cannot be 'softened' as a romantic abstraction. These specific forms of social change need to be defined clearly and, as White argues, in terms of 'particular times and places'. Further, the challenge is not simply to be couched in terms of the existing separation between 'children's ministries' or 'the youth' and 'the church' or 'ministers', via the existing missionary association models, which in terms of White's argument are the 'surrogate parent' (p. 4) of the youth. White has argued convincingly that this 'surrogacy' failed not only younger believers, as disciples of Jesus Christ, but also the church, of which the children and youth is (supposed to be) an integral part (p. 5). Children and young people in terms of the separation, association or missionary models as referred to earlier have been dominated and silenced firstly as the passive objects of missionaries, then secondly to become not only members and disciplined functionaries of church associations, but also, thirdly, the consumers of the products and programme offerings of the organisations. Their faith is either expressed or lived out in terms of being obedient (silent) receivers of a pure gospel, or towards mere compliance to the organisational needs - their witness in this sense serving to maintain the institution. Children must be seen and not heard. Their demands, but simply the reality within which they lived, however, challenged this. The daughter grew up and raised her voice. Therefore, in line with the proposal by White, it suggests a deeper theological engagement, or discernment of the church - a postcolonial missional ecclesiology.

\section{A postcolonial African missional ecclesiology for children's ministry}

Related to the DRMC, and later the Uniting Reformed Church in Southern Africa (URCSA), the starting point for a theological journey of liberation or transformation, which would be an integral dimension of a postcolonial ecclesiology, remains a covenantal theology of children and youth. In this respect, at the General Synod of URCSA in 2005, a study report speaks of 'a theology of childhood' (2005a:271, 2005b:37-38). The report states:

For a Reformed church attempting to integrate Calvinist impulses with contemporary African realities the answer to these questions can best be sought in a contextual covenantal theology. It is as a covenant community that the church of Jesus Christ gathers together to celebrate the meal of salvation and to baptise infants into membership of God's pilgrim people. (p. 271)

This report has value for this discussion on the disruption from the daughter. On the basis of a brief context analysis this report concludes, 'URCSA needs to take a new look at the way it treats its youngest members, in terms of the challenges posed by the quickly-changing context in which we live' (p. 272). It then moves to a section on 'Scriptural perspectives', indicating how the Reformed tradition, with the emphasis on the unity of God's covenant of grace in the Old and New Testaments, affirms infants as part of the covenant community. It still maintains therefore that infants should be baptised, may join in celebrating the Holy Communion and they participate in teaching (Ps 8:1-2; Mt 11:25). Our younger members are a blessing to the household and community (Ps 128:3-4), by learning and internalising the stories of the faith tradition (Deut 6:7), and in the New Testament, by making the presence of Jesus a reality (Mt 18:5; 25:40). This report might be brief and does not go into any exegetical depth in any of these Scriptural references, yet, it presents a key shift in the reading of the place of the younger members in the community, through the lens of the covenant. Here they are affirmed as younger members within the covenant community to be taken seriously and appreciated as persons in their own right (p. 273).

Children and within the covenant are, therefore, not (incomplete) the silenced members of a separate surrogate association 'outside' of the real church. These believers are not to be seen as the consumers of products - they are fellow sisters and brothers, fellow pilgrims with the people of God and also fellow witnesses of the gospel. These reflections cut at the heart of the colonial ecclesiology, with its inherent liberal, collegialism, where members join an association by their freedom of choice. Within the covenant, all generations come home and as we do this, we are on a pilgrimage of creating a warm home for all. It is in this that all generations are formed and reformed. Within this covenant ecclesiology, catechism of better faith development cannot be seen as a separate education system running alongside various membership-based associations and the church proper. The URCSA report indeed speaks of the 'faith development of the new generation of believers' as an organic and holistic process (2005a:277). The whole congregation becomes the space for the baptised members to participate in, share and receive the gifts of grace, in and with the world. This is an ongoing journey of transformation and reformation. This emphasis on reformation is not random; it is embedded in a 
broader shift, within African Christianity, which is leading in a particular direction, and exposes specific blind spots in our southern African gereformeerde ecclesiological heritage.

This African reformation is rooted in the confession that, being included in God's covenant, we are all part of God's bigger household (oikos). What this suggests is the need for different imaginations and a hopeful theology of home. Reference to the images of 'home', 'homestead' or 'household' (Mofokeng 1999:52), through the notion of oikos ['household'], not only blends into the African imagery of community, but then also takes up the challenges and African colonial experiences of landlessness, uprootedness in a context of xenophobia, forced migration, violence against children and child-headed households (p. 387). In this, it becomes a powerful symbol of hope. This correlates with the shift in at least the URCSA's official reflections towards the affirmation of the place and calling of the younger sisters and brothers in the covenant household.

This redrawing of the lines of our socially constructed identifications, based on missionary dualisms and generational separation, comes for the church, and those who share membership, not merely through social history; this is remixed in terms of the covenantal reality of being a family member, of being baptised. Being baptised, and celebrating the Holy Communion with sisters and brothers, young and old, not only affirms, but also forms this new household and forms us, fundamentally, as God's family. The sacraments form and enact now the new (safe) spiritual home, of which children, youth and older members are part of the roles they perform. The URCSA report concludes therefore poignantly:

- Christians need to be extremely careful of how they treat children at home, at school and in the church;

- The church should commit itself to work for the holistic development of children into mature and sensitive adults;

- Contemporary society confronts the church with serious new challenges in guiding children to grow up as Christians;

- Children should experience the church as a place of safety, warmth, acceptance and learning, where they are taken seriously and are appreciated as persons in their own right;

- Christian parents should learn to spend quality time with their children: playing with them, listening to them, reading and telling stories to them, taking them on outings, and protecting them from harm;

- Children should be a priority on the church's ministry agenda (2005a:273).

In terms of this postcolonial African missional ecclesiology catechism is not preparing children and teens for membership 'one day' - or 'preparation for Communion, but preparation for a life of service in the church and in the community ... Catechism is systematic empowerment for service ...' (p. 278). Remixing the church as a spiritual home for all, joined as God's family (Orobator 2000), this new community now transcends the separations and split personality within the church. We have shown this split personality between children and youth associations on the one hand and the church' on the other; between generations and between theological traditions, i.e., gereformeerde missionary ecclesiology on the one hand and the legacy of anti-colonial ecclesiologies on the other hand. This new community not only remixes the church as a spiritual home or missional household of faith, but it also reshapes the broader community and traditional social boundaries. Being part of this missional household is not defined by place, generation or even by race, but by grace.

Children are seen, included and heard.

\section{Acknowledgements Competing interests}

The author declares that he has no financial or personal relationships which may have inappropriately influenced him in writing this article.

\section{References}

Biko, S.B., 1978, I write what I like, Pikador Africa, Johannesburg

Boesak, A.A., 1966, Kerk en Verenigingswese. Koinonia Jaarblad, Die Teologiese Skool vir die N.G.Sendingkerk, Bellville.

Boesak, A.A., 1977, A farewell to innocence: A socio-ethical study on black theology and power, Orbis, Maryknoll, NY.

Boesak, A.A., 1984, Black and reformed: Apartheid, liberation and the Calvinist tradition, Skotaville, Johannesburg.

Boesak, A.A., 2009, Running with horses: Reflections of an accidental politician, Joho, Cape Town.

Bosch, D.J., 1991, Transforming mission: Paradigm shifts in theology of mission, Orbis, Maryknoll, NY.

Cannella, G.S. \& Viruru, R., 2004, Childhood and postcolonialization: Power, education, and contemporary practice, RoutledgeFalmer, New York.

Castells, M., 2010, The rise of the network society, Wiley Blackwell, West Sussex.

Castells, M., 2012, Networks of outrage and hope: Social movements in the internet age, Polity Press, Cambridge.

Cloete, G.D., and Smit, D.J.(eds.), 1984, 'n Oomblik van Waarheid, Tafelberg, Kaapstad. Crafford, D., 1982, Aan God die dank (Deel 1), NG kerkboekhandel Transvaal, Pretoria.

De Jong-Kumru, W., 2014, Postcolonial feminist theology: Enacting cultural, religious, gender and sexual differences in theological reflection, Lit Verlag, Münster.

Durand, J.J.F., 1984, 'Belhar-krisispunt vir die NG Kerke', in G.D. Cloete \& D.J. Smit (eds.), pp. 123-134, Tafelberg, Kaapstad.

Kinghorn, J., 1997, 'Modernisation and apartheid: The Afrikaner Churches', in R. Elphick \& R. Davenport (eds.), Christianity in South Africa: A political, socia and cultural history, David Phillip Publishers, Cape Town, 135-154.

Kriel, C.J., 1963, Die geskiedenis van die Nederduitse Gereformeerde Sendingkerk in Suid-Afrika 1881 - 1956, Paarlse Drukpers, Paarl.

Maluleke, T.S., 2008, 'May the black God stand please!: Biko's challenge to religion, in A. Mngxitama, A. Alexander \& N.G. Gibson (eds.), Biko lives! Contesting the legacies of Steve Biko, Palgrave MacMillan, New York.

Mofokeng, T.A., 1983, The crucified among the crossbearers: Towards a black Christology, J.H.Kok, Kampen.

Nederduitse Gereformeerde Sendingkerk, 1982a, Skema van Werksaamhede van die drie-en-twintigste vergadering van die hoogeerwaarde Sinode.

Nederduitse Gereformeerde Sendingkerk, 1982b, Handelinge van die drie-en-twintigste vergadering van die hoogeerwaarde Sinode.

Nederduitse Gereformeerde Sendingkerk, 1986a, Skema van Werksaamhede van die vier-en-twintigste vergadering van die hoogeerwaarde Sinode.

Nederduitse Gereformeerde Sendingkerk, 1986b, Handelinge van die vier-en-twintigste vergadering van die hoogeerwaarde Sinode.

Nel, M., 1983, Jeug en Evangelie, NG Kerk Boekhandel, Pretoria.

Nel, M., 2001, Jeugbediening: 'n Inklusiewe gemeentelike benadering, CLF, Bloemfontein

Nel, R.W., 2013, 'Discerning an African missional ecclesiology in dialogue with two uniting youth movements', DTh thesis, University of South Africa, Pretoria.

Orobator, A.E., 2000, The church as family: African ecclesiology in its social context, Paulines Publications Africa, Nairobi.

Robinson, P., 1984, 'Die Belhar-belydenis van 1982 in sendingperspektief', in G.D. Cloete \& D.J. Smit (eds.), 'n Oomblik van waarheid, pp. 49-59, Tafelberg, Kaapstad. 
Segovia, F.F., 1999, 'Postcolonial and diasporic criticism in Biblical studies: Focus, parameters, relevance', Studies in World Christianity 5(2), 177-195. http://dx.doi. parameters, relevance', Studies
org/10.3366/swc.1999.5.2.177

Sugirtharajah, R.S., 'Postcolonialism and Indian Christian theology', Studies in World Christianity 5(2), 229-240.

Sugirtharajah, R.S., 2001, The Bible and the third world, Cambrigde University Press, Cambridge.

Sugirtharajah, R.S., 2003, Postcolonial reconfigurations: An alternative way of reading the Bible and doing theology, SCM Press, Uniting Reformed Church in Southern Africa, London.
Terblanche, D.J.M., 1966, 'Die Ned Geref Kerk en sy naskoolse jeug', DTh thesis, University of Stellenbosch, Stellenbosch.

Uniting Reformed Church in Southern Africa (URCSA), 2005a, Acts of Fourth General Synod.

Uniting Reformed Church in Southern Africa (URCSA), 2005b, Agenda for Fourth General Synod.

Ward, P., 2002, Liquid church, Baker Books, Grand Rapids, MI.

White, D., 2005, Practicing discernment with youth: A transformative youth ministry approach, Pilgrim Press, New York. 